Przegląd Badań Edukacyjnych Educational Studies Review

ISSN $1895-4308$

nr 27 (2/2018), s. 167-181

METAANALIZY

BADAŃ

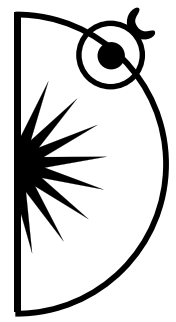

Eliza Czerka-Fortuna

ORCID iD: 0000-0002-9219-9330

University of Gdańsk, e-mail: e.czerka@ug.edu.pl

\title{
Learning Systems. Development of Professional Competences of School Heads and Teachers
}

http://dx.doi.org/10.12775/PBE.2018.023

\begin{abstract}
The aim of the article is to provoke reflection on the professional competences of head teachers of schools and of teachers, especially in the area of educational leadership. Research on this subject (among others, Mazurkiewicz, 2011, 2014, 2014a) shows that the dominant tradition of education in the Polish school leads to a reduced vision of leadership perceived as a strategy for managing the institution and for exercising control over the staff/students. The consequence is the alienation of school heads who focus on solving administrative problems, and to a small extent engage in educational problems. A similar dilemma applies to teachers who, in spite of their knowledge of many teaching methods and tools, use common patterns in their contact with the student. The article proposes getting out of the crisis by referring to Richard Ryan and Edward Deci's theory of self-determination, which puts emphasis on building positive motivation through the implementation of such needs as autonomy, competence, and affiliation. The implementation of this concept in the field of education can increase the involvement of all entities that are a part of the education process, which in turn is a guarantee of greater efficiency and educational success.
\end{abstract}

Key words: educational policy, educational leadership, self-determination theory.

Every change in the educational system arouses mixed feelings, not only because of the modification of the educational structure and learning objectives, 
but because it impacts the sense of competence and affiliation of educational staff - some teachers turn out to be useless, another group has to retrain, and many teachers are going through a crisis of identification with their professional role. Especially in Poland, where we are dealing with permanent transformations, it provokes justified resistance. On September 1, 2017, another reform, which is very controversial, primarily owing to the omission of public consultations and the failure to take into account the voices of resistance from education employees, and from parents and students, came into effect. The aim of the article is not, however, to make a balance of profits and losses which are a consequence of the proposed solutions. I would like to propose a step further, to consider how the resulting ferment can be used to design the development of school and its employees. For this purpose, it is worth re-defining the competences of educational staff and considering strategies that enable occupational professionalism to be developed.

\section{What is educational leadership?}

If we look at school as a collection of related elements then, according to the theory of systems (Bertalanffy von, 1984), these elements interact with each other on the basis of feedback. Changing one component causes a reaction in others, which causes the reorganisation of the whole set. Therefore, an institution like school should be analysed holistically, not focusing on individual hierarchical levels or areas of knowledge, but on the network of mutual relations, which builds the institution's identity and its organisational culture. As a researcher of education, M. Schratz (2014) demonstrates that “(...) neither the action within the system nor the mere strengthening and support of people will contribute to improving the results" (2014, p. 31). From the perspective of the author, the only possible way to arrive at a constructive development of school is to create a "learning organisation", where the learning process will be multi-level and multidirectional. In the context of leadership, each decision made by the school management should affect four areas: people (teachers, students and other stakeholders), curriculum, culture (understood as the atmosphere at the workplace), and structure. These areas merge into various subsystems (e.g. class teams, interdisciplinary teams of teachers), making both individual acquisition of knowledge and the creation of homogeneous or heterogeneous learning communities possible (Schratz, 2014, p. 28). If we additionally emphasise that the teaching and learning processes are no longer clearly understood as the transmission of knowledge from the teacher to the student, but as joint posing 
of problems and finding solutions, this makes it possible to think about school as a conglomerate of learning subsystems that can operate independently, at the same time identifying themselves with the mission and vision of the institution. As educational practice shows, it is the sense of community, and autonomy that are the guarantors of effectiveness (Krzyżanowska, Stec, 2011). Unfortunately, postulates that are the result of research analyses are not always implemented in practice. This may result from ignorance of the latest developments in interdisciplinary research on education or from cultivation of beliefs that do not lead to effective actions, but give a sense of security and protect professional identity. As G. Mazurkiewicz (2012) argues, it is the mental models (in the form of ideologies, beliefs, and views) of educational leaders that may cause the low effectiveness of educational activities. The author's research on the ways of perceiving school functions and leadership styles shows that in the opinion of head teachers, socialising the student, which they understand as the choice of future occupation and acquisition of a specific resource, universal for the whole community, that is the cognitive function, is the most important role of school (Mazurkiewicz, 2012, p. 46-49). To a lesser extent, the respondents were in favour of a developmental function, which is combined with emphasis on individual development of the student, and almost none of the respondents was an advocate of combining education with social change (reconstruction of education goals against marginalisation and exclusion of individuals or social groups) (Mazurkiewicz, 2012, p. 50). Thus, the head teacher's way of thinking about education is very reductionist. Above all, it aims at maintaining the status quo, which shows that teachers are supporters of the traditional educational concept, which may block the start of adaptation to change. On the other hand, a narrowly understood emphasis on the development of cognitive competences (acquisition and reproduction of a predetermined resource of information), leads to the perception of the learning process as a "continuous dry run" (Mazurkiewicz, 2012 , p. 52), without being able to engage in real problems. This limits the student's ability to make decisions or deal with both failure and success, resulting in passivity at school, as well as reluctance to engage in public life.

Conservatism is also characteristic of the management style preferred by head teachers. $62 \%$ of respondents choose the styles of leadership which are related to the classical style (classical or classical-visionary, classical-organic, or classical-transactional). Head teachers want to perceive themselves as strong leaders, confident of their competences, and using consultancy only in exceptional situations (Mazurkiewicz, 2012, pp. 69-72). In practice, it is a vision difficult to implement, primarily because we overestimate the impact of 
personality dispositions on action ${ }^{1}$. Forgetting about the situational context, we do not use the group forms of leadership which, especially in the school environment, would be justified (Mazurkiewicz, 2014a, pp. 50-51). When writing about group leadership, I mean participative leadership (distributed), which consists in using the leadership competences of employees by including them in the decision-making process regarding the school. In this situation, both teachers and non-teaching employees have a greater sense of agency and are more involved in educational processes. A statement of a primary school teacher, a member of the implementation team at the County Lane on the role of the head teacher that "The head teacher fully supports our experimentation. As the highest decision-making body at school, she consolidates our efforts and contributes to their implementation"(Jones, 2013, pp. 127-128) is an example of distributed leadership. Therefore, modern leadership should be understood more as an "organisational quality - the effect of cooperation of many people" rather than a form of exercising control, based additionally on the sole responsibility of the leader (Mazurkiewicz, 2011, pp. 25-27).

The transfer of concentration from the leader as a person to the process of leadership reflected in structures, processes, and relationships (West-Burnham, 2004, p. 4), obliges the leader to develop broader competences compared to those required in a situation where tasks are not delegated. Searching for resources in the environment can be a tedious process and requires diagnostic, conceptual, and interpersonal skills. Meanwhile, the superiors of Polish schools (Hernik et al., 2014) admit that they lack management competences, especially when it comes to planning and internal evaluation. What is worse, the respondents believe that the barrier in acquiring these resources is the lack of an adequate training offer (Hernik et al., 2014, p. 44). From the report "Diagnosis of school heads' demand for research results and other information useful in school management" (2012), we learn that the knowledge of school management is mainly derived from informal contacts and internet forums, because advisory support from supervisors and the school's governing body is insufficient. It is also worth noting that research support for the school leader is insufficient. Only $4 \%$ of respondents surveyed by the Institute for Educational Research (2012) had contact with one or more research reports during the year. The aversion to consult research publications is caused by the incompatibility of the results of research with the reality in which head teachers work. School superiors expect

${ }^{1}$ In social psychology, this phenomenon is referred to as the fundamental error of attribution (including Wojciszke, 2004, p. 103). 
analyses showing the multifaceted functioning of the institution and specific environmental conditions of the school (i.e. local environment, cooperation with parents, or educational problems) (Diagnoza..., 2012). Unfortunately, research on such a large scale is carried out rarely.

One should also not forget that difficulties in building educational leadership may result from prosaic reasons such as the problem of finding people with sufficiently high qualifications who would undertake the task of building the leadership process, and encountered conditions enabling them to achieve their goals (Pyżalski, 2014, p. 51).

\section{The teacher's condition in the light of ambivalent requirements}

The individual role of the teacher consists in both social precepts, assimilated in the process of socialisation (during studies and while gaining professional experience in the school environment) as well as the personality-based definition of the role, that is, the vision of characterological predispositions that the teacher should have. Sometimes these two components are contradictory. If we additionally take into account the fact that social role precepts are a result of the expectations of various social groups, and in the case of teachers they are usually school heads, students and their parents, whose claims are independent of each other, we have to do with a vision elements of which are mutually exclusive. Also, the too idealistic image of the personality definition may be very close to the conditions of the educational reality (Rubacha, 2001). Thus, the teacher's task is to oscillate between multiple groups of roles that he/she implements (e.g. an English teacher-educator-implementer of the school's mission) and to attempt at dealing with the constant sense of non-fulfilment in one of these areas. Not every teacher accepts the ambivalence inscribed into this profession. As noted by R. Leppert (1998, p. 219), there are three ways to act as a teacher: an adaptive technician, a reflective practitioner, or a transformative intellectual. The adaptive technician is limited to the transfer of knowledge in accordance with the chosen patterns, the reflective practitioner builds his/her own work technique, which is the result of reflection on his/her own role, and the transformative intellectual is involved in social change. It seems, however, that the modern teacher is often limited to the first role and "(...) no longer introduces the student into the secrets of community life, does not teach him/ her to take his/her place. He has a limited scope of knowledge to convey to the student and should do it as efficiently as possible (...)" (Mikiewicz, 2008, p. 93) 
What makes teachers often perform their functions fragmentarily? It would be worth looking at teachers as a subject of education, because, as M. NowakDziemianowicz (2008, p. 131) argues, "negative selection preparing for the teaching profession begins at the university level". While it can be assumed that teachers receive knowledge of the methodology of teaching the subject in which they specialise, too few hours of psychological and pedagogical subjects limit their ability to work with the group and their educational competences (Dziemianowicz, 2008, p. 131). In fact, educators often break away from educational functions themselves, arguing that this is the domain of the family, not school (Groenwald, 2015, p. 137), which indicates that they misinterpret the purpose of education. The results of the TALIS study $(2013)^{2}$, drawing attention to the decline of teachers' needs in the field of professional development, are not very optimistic, either. In comparison to the previous round of research (2008), "the level of the need for knowledge and understanding of a given subject decreased from $17 \%$ to less than $2 \%$, computer skills from $22 \%$ to just $11 \%$, while teaching students with special needs - from 29 to $14 \%$ "(TALIS, 2013, p. 26). This result is not surprising given the low percentage of Poles who participate in continuing education $-5 \%$. (Perspektywa Uczenia się Przez Całe Życie (Perspective of Lifelong Learning), 2013, p. 18). Nevertheless, it is worth pointing out the barriers that teachers identify in relation to the insufficient level of implementation of professional development. These are: too high costs of professional development, the lack of appropriate offer, shortage of time related to family responsibilities, and the lack of incentives (TALIS, 2013, p. 27). In addition, the low level of motivation of teachers associated with self-education may be dictated by poor social conditions (Vidović, Domović, 2013, p. 225) and the low prestige of this profession. Surveys conducted by the "Polityka weekly" showed that only $36 \%$ of respondents believe that the teaching profession is of an elite character (Janicki, 2017). All the above-mentioned factors, and, in addition, a relatively rare formal assessment of teachers' work and low probability of obtaining a negative assessment (TALIS, 2013, p. 32), may suggest that a significant group of teachers is not sufficiently motivated to work and their way of functioning at school resembles a survival strategy rather than is the result of real engagement. This conclusion may be alarming when we take into account the extent to which the teacher's competences translate into student achievements (Kunter et al., 2013, p. 815).

2 TALIS - Teaching and Learning International Survey, focusing on the diagnosis of the learning environment and the work of teachers, carried out every 5 years as a standard. In 2015, the Ministry of National Education withdrew from participation in the study (Wittenberg, 2015). 


\section{From the competence of the teacher to the competence of students. The usefulness of emotions in the educational process}

According to the European Commission, the development of the paradigm of "lifelong learning" requires primarily the shaping of social competences and digital competences (which, as M. Dziewguć argues, overlap as "digital competences are the ability to function and operate in a network environment and relationships with other people" (Dziewguć, 2016, p. 37). In addition, it is important to develop meta-competence, i.e. the ability to learn, adapt to change, and manage the flow of information (European Commission, 2011, see: Caena, 2014, p. 312). EU recommendations force change in the way of thinking about education, putting more emphasis on generating knowledge than reconstructing it. Therefore, the need to redefine teacher competences is not a simple task, because expectations of what is required from teachers vary depending on the concept of education. Other requirements will be formulated if we are supporters of the general paradigm, and yet others if we are advocates of personalism or pragmatism (Nowak-Dziemianowicz, 2008, p. 134). Therefore, to reduce the classification chaos, I will limit myself to presenting six key types (paradigms) of the teacher's profession whose descriptions contain the characteristics of the desired competences.

- teacher as a reflective agent - developing critical thinking in the aspect of tasks that he/she should realise and the experience he/she acquires,

- teacher as knowledgeable expert - in the field of the subject which he/ she teaches, but also interdisciplinary knowledge; competent in working with an individual student and with a group,

- teacher as a skilful expert - who has a wide range of information that he/ she uses in the process of critical thinking, knowledge acquisition, and direct action,

- teacher as a classroom actor - which requires competence in integrating the group and dealing with diversity,

- teacher as a social agent - focused on building community through dialogue and cooperation,

- teacher as a lifelong learner - taking responsibility for acquiring, shaping and developing knowledge, by taking action in various contexts" (Paquay and Wagner, 2001; Schratz and others, 2007, see: Caena, 2014, p. 316).

The presented patterns emphasise the need of the teacher to have high intellectual competences, but also well-developed emotional intelligence. Besides, 
emotional competences are closely related to cognitive competences and in the process of discovering the world (learning) a person uses both of these channels simultaneously (among others Oatley, Jenkins, 2003; Levis, Haviland-Jones, 2005). Emotional competences can include intrapersonal (self-awareness, selfassessment and self-control mechanisms), interpersonal (empathy, but also cooperation and leadership) and praxeological competences (related to motivation to act and develop conscientiousness) (Goleman, 2012). Although each of these areas can be described in detail, I will limit myself to competences related to the development of motivation, which can be especially useful for teachers. In order to do this, I will characterise Richard Ryan and Edward Deci's concept of self-determination, hardly known in the pedagogical literature of the subject (2000, 2006, 2008, 2012).

\section{Conditions of engagement in the learning/teaching process. Theory of self-determination}

The starting point for Richard Ryan and Edward Deci's theory was the analysis of motivation, traditionally distinguished between intrinsic and extrinsic. In many theories, internal motivation is perceived as conditioned by many psychological, emotional, and social processes, a state of readiness to undertake activity and responsibility for one's own functioning. It also involves vitality, which makes it possible for people to act autonomously and be persevering in the face of challenges (Deci, Ryan, 2008). On the other hand, external motivation generated by the system of social expectations does not bring such measurable effects and leads to release from pressure rather than to a sense of fulfilment. In the educational context, this division presents many methodological problems that can be included in the question: What type of motivation should school concentrate on and is it possible to reconcile learning objectives with the needs of students?

A certain solution to this dilemma is the classification of external motivation proposed by the authors (Ryan, Deci, 2000). The researchers distinguished its four types: external regulation, introjection, identification, and integration. External control is connected with undertaking specific behaviours in order to implement social expectations which are regulated by means of reward and punishment. In the case of introjection, the action is motivated by the desire to avoid negative emotions, such as a sense of shame or guilt or to gain social approval and feel pride (that is, it is still a motivation controlled from the outside, although based on internal motives). More advanced forms of motivation are 
identification, which is associated with the awareness of one's values and goals, and integration - when social standards become consistent with the identity of the individual. It is not difficult to guess that in the case of external motivation of students, we will have to deal with less effort engaged in learning and with a greater tendency to blame others for failures, e.g. teachers. In turn, the introjective orientation involves a greater involvement, but with the feeling of strong negative emotions and problems with coping with failures. School satisfaction, greater effort, and better coping strategies are the domain of students achieving integration (Decy, Ryan, 2000, p. 73).

From the perspective of the self-determination theory, a question arises of how to work on integrating external motivation with the student's identity. According to the authors, the condition for starting this process is to meet three needs: the need of relatedness, competence, and autonomy. The need for belonging is built by creating positive ties with the environment - firstly, with parents, then with members of other social groups, in the process of secondary socialisation. Values and patterns transmitted by "significant others" can be internalised by students, especially when the child and guardian are tied by an emotional bond (Ryan, Deci, 2000, p. 70). This is confirmed in the research conducted by Kochańska and colleagues (see: Kadzikowska-Wrzosek, 2013, p. 84) on the so-called "committed compliance", which the author defines as acceptance and implementation by a child of rules and norms inculcated by parents, in contrast to "situational driver compliance", which is subordinating to the will of parents only when children are subject to pressure. Instrumentalisation of the teacher's role (specialised and short-term contact), which we often deal with in a modern school (Mikiewicz, 2005, p. 119) makes it difficult to build ties, and according to Ryan and Grolnick's research (1986, see: Ryan, Deci, 2000, p. 71) the teacher's emotional commitment is very important for developing students' motivation.

The need for relatedness can be understood more broadly than as Ryan and Deci wrote. A teacher who is an authority for students provides them with identification that forms the basis for both individual and group identity. And as we know from the report "The secret of success, the reasons for failure: educational value added in general high schools" (Krzyżanowska, Stec, 2011), effective schools are those that are based on networks built on trust and respect, and mutual emotional connections. Thus, a sense of belonging can be understood broadly, as building relationships with people, but also belonging to the environment and identifying with the ethos of the institution.

The second factor that builds positive motivation is the sense of competence, which is closely related to the need for building close social relations and 
obtaining positive feedback from the carer. Relying on the research of Anderson, Manoogian and Reznick (1976, see: Ryan, Deci, 2000, p. 71), if children perform an interesting task before adults who ignore them, they do not develop internal motivation. The dominant attitude of the teacher, assessment based on the demonstration of "ignorance", make it impossible to build motivational resources. Unfortunately, Olga Bąk's (2015) research indicates that teachers generally provide more negative than positive information. Moreover, while the positive information relates to school tasks, the negative focus is mainly on students' behaviour and to a small extent affects the change of negative reactions (Bąk, 2015, p. 89).

Ryan and Deci understand the third need - autonomy, as undertaking actions that are related to both intrinsic and extrinsic motivation. On the one hand, it will be following one's interests and activities that make one satisfied, and on the other hand, the implementation of external standards, which are perceived as related to one's own goals. With regard to the research on students, autonomous support stimulates internal motivation, curiosity and taking up challenges (Ryan, Deci, 2000), that is why students taught in the directive way lose initiative and are less effective, especially in the activities that require creativity (Ryan, Deci, 2000, p. 71). These conclusions are reinforced by the research of Gough and Mc Gregor, and Woo (see: Ryan, Deci, 2006) who clearly indicate that autonomous people are more committed and productive.

Therefore, is it advisable for teachers and educators to abandon the directive way completely? The authors of the theory do not perceive this issue in such a radical way. They clearly point out that supporting autonomy does not mean being indulgent and encouraging pupils to do only the things they want to do (Deci, Ryan, 2012), but it is recognising the needs of the pupil and setting the framework for action when the pupil expects directions.

The basic conclusion resulting from the theory is the conviction that one of the teacher's significant skills is to support the motivation of students through the teacher's presence and positive response to the pupil's needs. However, it must be remembered that this is a form of feedback because the teacher's skills in this area will largely be linked to self-motivation. And the path is similar here: a sense of autonomy, competence, and relatedness gives a chance for effective motivation, especially for those teachers whose internal motivation and internalisation of external standards are poorly developed. Unfortunately, the lack of a reliable diagnosis poses a certain difficulty in the realisation of this postulate. We do not know to what extent teachers feel autonomous in their work and whether their need of belonging and sense of competence are being 
developed at school. However, it is worth disseminating the ideas taken from the theory of self-determination among teachers and people managing education, which may be an introduction to the gradual, evolutionary reconstruction of mental models.

\section{School in the azure colour. Towards educational success}

In the recently popular book "Reinventing organizations", Frederic Laloux (2015) develops the concept of turquoise organisations as institutions which, he claims, can embody the idea of self-realisation. Postulated by the Belgian advisor and coach, the Turquoise Revolution enables the creation of an environment in which the transition from external to internal evaluation will be visible, departure from hierarchisation to cooperation and resignation from rigid rules that are a tool of control, to building internal discipline and autonomy that make the realisation of both one's own needs and social goals possible. The Laloux concept is not a utopian vision, as evidenced by the examples of institutions presented by the author, where new self-management strategies were implemented. Selfmanagement, based on building relationships between employees, developing the "fullness" of identity, and awareness of one's own direction of development, are the three pillars on which this idea is based. Among many case studies in the field of energy, IT consulting, clothing, food, and media industries presented in the book, we will also find school. ESBZ - a public school in Berlin implements an innovative curriculum and, at the same time, proposes a new organisational model. In this educational institution, children are given full responsibility for their own education. "To a large extent, students teach themselves and each other. Adults are mainly mentors and coaches, and they function as teachers in the traditional sense of the word only when there is a need" (Laloux, 2015, p. 119). The school develops students' autonomy as well as competences in planning and managing their own development. In addition, students receive emotional support - each child has a weekly meeting with their teacher, with whom he/she discusses progress, problems and plans, which allows both parties to get to know each other well and develop fruitful cooperation.

We also have examples of similar solutions in Poland, although they are usually implemented in the private sector of education. Apart from the funds which the owners of these schools have for the development of their own concept, I have an impression that educational leaders are first of all people who are great observers and can recognise the expectations of students and their parents, while recognising broadly understood social changes and not staying passive 
in their face. These are, of course, competences that any teacher can develop if he/she is offered (or he/she creates for himself/herself) the right conditions. From the above-mentioned report "Tajemnica sukcesu, przyczyny porażki: edukacyjna wartość dodana w liceach ogólnokształcących" (The secret of success, the reasons for failure: educational value added in general high schools) (Krzyżanowska, Stec, 2011), it can be concluded that what determines the high quality of a school is a broad understanding of the purpose of education. "Good schools" are the institutions in which students are a reference point, which means that the care and support they are surrounded by is prognostic and not interim (ad hoc). The aim is not only passing final exams, but the broadly understood life interest of a young person. Therefore, "teachers are treated as resources that should be allocated according to the needs of students" (Krzyżanowska, Stec, 2011, p. 133). The pupils are also treated as resources under high expectations, while giving them many tips to solve problems, which helps them to build a sense of agency.

The implementation of the recommendations presented in the article requires a change in the method of teacher education. From the analyses of the Institute of Educational Research (Fedorowicz et al., 2015, p. 40) we know that "neither the studies nor the training curricula satisfy [their - E.Cz.] real needs". Perhaps the reason for the inadequacy of educational activities is the lack of a deeper diagnosis of these needs or the lack of knowledge about the actual competences of teachers, which would help to identify the "gap" requiring compensation. On the other hand, it becomes extremely important to prepare candidates for the teaching profession, which in higher education begins to be implemented even through ministerial contests, e.g. "Studiujesz? Praktykuj!" (Are you studying? Practice!) or contests for academic career offices. The institutional methodological support system for teachers and school heads also needs to be reconstructed (Fedorowicz et al., 2015).

In addition to institutional solutions, it is worth starting by educating employees of education by presenting "good practices" and promoting educational leaders, who can encourage the seeking for new solutions rather than legal acts.

\section{References:}

Bąk, O. (2015). Informacje zwrotne w szkole. Perspektywa nauczycieli i uczniów. Teraźniejszość-Człowiek-Edukacja, 3(71), pp. 85-100.

Bertalanffy von, L. (1984). Ogólna teoria systemów: podstawy, rozwój, zastosowania. Warszawa: PWN. 
Caena, F. (2014). Teacher competence frameworks in Europe: policyas-discourse and policy-as-practice. European Journal of Education, 3(49), pp. 311-331.

Deci, E. L., Ryan, R. M. (2008). Self-determination theory: A macrotheory of human motivation, development and health. Canadian Psychology, 49, 3, pp. 181-185.

Deci, E. L., Ryan, R. M. (2012). Self-determination theory in health care and its relations to motivational interviewing: a few comments. Journal of Behavioral Nutrition and Physical Activity, 9, 24.

Diagnoza zapotrzebowania dyrektorów szkól na wyniki badań i inne informacje przydatne w kierowaniu szkoła. Raport tematyczny (2012). Warszawa: Instytut Badań Edukacyjnych.

Dweck, C. (2013). Nowa psychologia sukcesu. Warszawa: Muza.

Dziewguć, M. (2016). Zatrzymajmy eksport talentów. In: A. Leśniewicz, P. Zbieranek (ed.). Kompetencje przyszłości - jakich postaw i umiejętności potrzebujemy? Gdańsk: Instytut Badań nad Gospodarką Rynkową.

Fedorowicz, M., Biedrzycki, K., Karpiński, M., Rycielska, L., Sitek, M., Walczak, D. (2015). Dynamika przemian w edukacji i diagnoza problemów do rozwiązania. Warszawa: IBE.

Goleman, D. (2012). Inteligencja emocjonalna. Poznań: MediaRodzina.

Groenwald, M. (2015). Między trudnym wyborem a „sytuacją bez wyjścia”. O moralnych i pozamoralnych uzasadnieniach nauczycielskich decyzji. Teraźniejszość-CzłowiekEdukacja, 1(69), pp. 133-150.

Hernik, K., Malinowska, K., Piwowarski, R., Przewłocka, J., Smak, M., Wichrowski, A. (2014). Polscy nauczyciele i dyrektorzy na tle międzynarodowym. Główne wyniki badania TALIS 2013. Warszawa: Instytut Badań Edukacyjnych.

Janicki, M (2017). Elita znika. Polityka, http://www.polityka.pl/tygodnikpolityka/kraj/1710972,1,kto-w-polsce-nalezy-do-elity.read [access: 4.07.2017].

Jones, J. (2013). Tworzenie uczącej się społeczności w szkole i w sieci. Doświadczenia brytyjskie. In: D. Elsner (ed.). Sieci wspótpracy i samoksztatcenia. Warszawa: Wolters Kluwer.

Kadzikowska-Wrzosek, R. (2013). Siła woli. Autonomia, samoregulacja i kontrola działania. Sopot: Smak Słowa.

Kunter, M., Baumert, J., Voss, T., Klusmann, U., Richter, D., Hachfeld, A. (2013). Professional competence of teachers: effects on instructional quality and student development. Journal of Educational Psychology, 3(105), pp. 805-820.

Krzyżanowska, Ł., Stec, M. (2011). Tajemnica sukcesu, przyczyny porażki: edukacyjna war- 
tość dodana w liceach ogólnokształcacych. Raport z jakościowego modulu badania. Warszawa: IFiS PAN.

Laloux, F. (2015). Pracować inaczej (Reinventing Organizations). Warszawa: Studio Emka.

Lewis, M., Haviland-Jones, J. M. (2005). Psychologia emocji. Sopot: GWP.

Mazurkiewicz, G. (2014). Edukacja i przywództwo. Krakow: Wyd UJ.

Mazurkiewicz, G. (2014a). Przywództwo edukacyjne - ambitny projekt zmiany. In: S.M. Kwiatkowski, J. Madalińska-Michalak (ed.). Przywództwo edukacyjne. Wspótczesne wyzwania. Warszawa: Wolters Kluwer.

Mazurkiewicz, G. (2011). Przywództwo dla uczenia się. Jak wyjść poza schemat? In: S. M. Kwiatkowski, J. M. Michalak, I. Nowosad (ed.). Przywództwo edukacyjne w szkole i jej otoczeniu. Warszawa: Difin.

Mikiewicz, P. (2005). Społeczne światy szkół średnich. Wrocław: Dolnośląska Szkoła Wyższa Wydawnictwo Naukowe.

Mikiewicz, P. (2008). Nauczyciel jako istotny aktor społecznego świata szkoły. In: P. Rudnicki, B. Kutrowska, M. Nowak-Dziemianowicz (ed.). Nauczyciel: misja i zawód? Społeczne i profesjonalne aspekty roli. Wrocław: Dolnośląska Szkoła Wyższa Wydawnictwo Naukowe.

Nowak-Dziemianowicz, M. (2008). „Wielki przegrany współczesności”. Polski nauczyciel jako podmiot i przedmiot kształcenia. In: P. Rudnicki, B. Kutrowska, M. Nowak-Dziemianowicz (ed.). Nauczyciel: misja i zawód? Społeczne i profesjonalne aspekty roli. Wrocław: Dolnośląska Szkoła Wyższa Wydawnictwo Naukowe.

Oatley, K., Jenkins, J. M. (2003). Zrozumieć emocje. Warszawa: PWN.

Perspektywa Uczenia się Przez Całe Życie (2013). Załącznik do uchwały Nr 160/2013 Rady Ministrów z dnia 10 września 2013 r.

https://men.gov.pl/wp-content/uploads/2014/01/pll1_2013_09_10zal_do_uchwaly_rm.pdf [access: 4.09.2017].

Pyżalski, J. (2014). Kompetencje przywódcze dyrektorów szkół i placówek w krajach Unii Europejskiej oraz Stanach Zjednoczonych. Warszawa: Ośrodek Rozwoju Edukacji.

Rubacha, K. (2001). O społecznej roli nauczyciela w świetle teorii roli indywidualnej Levinsona. Teraźniejszość-Człowiek-Edukacja, 4(16), pp. 39-52.

Ryan, R. M., Deci, E. L. (2000). Self-determination theory and the facilitation of intrinsic motivation, social development, and well-being. American Psychologist, 55, 1, pp. $68-78$. 
Ryan, R. M., Deci, E. L. (2006). Self-regulation and the problem of human autonomy: does psychology need choice, self-determination, and will? Journal of Personality, 74, 6.

West-Burnham, J. (2004), Building Leadership Capacity - Helping Leaders Learn. In: J. Creasy, P. Smith, J. West-Burnham, I. Barnes (ed.). Meeting the Challenge-Growing Tomorrow's School Leaders. National College for School Leadership. https://www. rtuni.org/uploads/docs/meeting-the-challenge-growing-tomorrows-school-leaders.pdf [access: 29.07.2017].

Wittenberg, A. (2015). MEN wycofuje się z badań nauczycieli. Niejasne thmaczenia resortu.

http://edukacja.dziennik.pl/aktualnosci/artykuly/481248,men-wycofuje-sie-z-badannauczycieli-talis-tlumaczenia-resortu-koszty.html [access: 2.09.2017].

Wojciszke, B. (2004). Człowiek wśród ludzi. Zarys psychologii społecznej. Warszawa: Scholar.

Vidović, V., Domović, V. (2013). Teachers in Europe - main trends, issues and challenges. Croatian Journal of Education, 3, pp. 219-246. 